E3S Web of Conferences 1, 08005 (2013)

DOI: $10.1051 / \mathrm{e} 3$ sconf/20130108005

(c) Owned by the authors, published by EDP Sciences, 2013

\title{
Investigation of Tin and Molybdenum concentrations in the Soils in the southern part of the Silesian Upland
}

\author{
W. Bureć-Drewniak $^{1}$, I. Jaroń ${ }^{1}$, J. Kucharzyk $^{1}$, W. Narkiewicz ${ }^{1}$ and A. Pasieczna ${ }^{2}$ \\ ${ }^{1}$ Central Chemical Laboratory, Polish Geological Institute - National Research Institute (PGI-NRI), 4 Rakowiecka \\ Street, 00-975 WARSAW (Poland), e-mail: wbur@pgi.gov.pl \\ ${ }^{2}$ Environmental Geology Department, Polish Geological Institute - National Research Institute, 4 Rakowiecka Street, \\ 00-975 WARSAW (Poland)
}

\begin{abstract}
Majority of soils from the southern part of the Silesian Upland (Poland) are highly degraded and contain elevated levels of heavy metals. Detailed studies, including dissemination, mobility and bioavailability have been conducted for most heavy metals, except tin and molybdenum. Therefore, the purpose of presented studies was evaluation of molybdenum and tin pollution and determination of their mobility and bioavailability in all soil types derived from the investigated area. A total of 9920 soil samples, including 5256 topsoil samples and 4664 subsoil samples were analyzed. Comparison of elements concentration between topsoil and subsoil allows identification of the source of pollution (natural or anthropogenic) of tested elements.
\end{abstract}

Key words: molybdenum, tin, soil, mobility, bioavailability

\section{Introduction}

Majority of soils from the southern part of the Silesian Upland (Poland) are highly degraded and contain elevated levels of heavy metals. Detailed studies, including dissemination, mobility and bioavailability have been conducted for most heavy metals, except tin and molybdenum [1]. Those elements were neglected or roughly examined in previous studies. The previous data inform that, depending on soil type, the tin concentration was between $0.3-10.0 \mathrm{mg} \cdot \mathrm{kg}^{-1}$ with the average content in $2.5 \mathrm{mg} \cdot \mathrm{kg}^{-1}$, while the molybdenum ranged within 0,1 - $6,0 \mathrm{mg} \cdot \mathrm{kg}^{-1}$ [2]. By contrast, the present studies, performed in the GEMAS (GEochemical Mapping of Agricultural Soils and Granzing Lands in Europe) project, showed that the average concentration of $\mathrm{Sn}$ is $0.05-1.71 \mathrm{mg} \cdot \mathrm{kg}^{-1}$, while the average Mo concentration is $0.1-2.6 \mathrm{mg} \cdot \mathrm{kg}^{-1}$ [3]. However, those data refer only to agricultural soils. Therefore, the purpose of presented studies was evaluation of molybdenum and tin pollution and determination of their mobility and bioavailability in all soil types derived from the investigated area.

\section{Materials and Methods}

A total of 9860 soils samples (5223 topsoil and 4637 subsoil) were analyzed in the first research step. Those samples were collected in 2007/2008 and were used for preliminary screening. Based on those studies we selected
33 sampling sites for a detail analysis. The soils samples, chosen for further analysis, were collected in 2011 from two depths: 33 topsoil $(0,0-0,3 \mathrm{~m})$ and 27 subsoil $(0,8-1,0$ $\mathrm{m})$. All soil samples were air-dried, sieved ( $2 \mathrm{~mm}$ nylon sieved) and ground in agate planetary ball mills to a grain size $<0,06 \mathrm{~mm}$. Samples were treated with aqua regia, $1 \mathrm{~g}$ sample with $6 \mathrm{ml} \mathrm{HCl}$ and $2 \mathrm{ml} \mathrm{HNO}_{3}$ for 1 hour at the temperature $95^{\circ} \mathrm{C}$ in the aluminium heating block thermostat (to final volume of $50 \mathrm{ml}$ ). For selected samples, sequential extractions according to BCR method $[4,5]$ was used for preliminary evaluation of mobility and bioavailability. The following leaching solutions were used: (i) actate acid $\left(0.1 \quad \mathrm{~mol} \cdot \mathrm{L}^{-1}\right)$, (ii) hydroxylammonium chloride $\left(0.5 \mathrm{~mol} \cdot \mathrm{L}^{-1}\right)$, (iii) hydrogen peroxide $\left(8.8 \mathrm{~mol} \cdot \mathrm{L}^{-1}\right)$ and ammonium acetate $(1.0$ $\left.\mathrm{mol} \cdot \mathrm{L}^{-1}\right)$; and (iv) aqua regia. The "total" concentrations of molybdenum and tin as well as other elements ( $\mathrm{Zn}, \mathrm{Fe}$, $\mathrm{S}, \mathrm{Pb}, \mathrm{Cu}$ ) were analyzed by inductively coupled plasma optical emission spectrometry ICP-OES, iCAP6500 DUO (Thermo Scientific). Mineralogical composition was investigated by the use of X-ray diffractometer (XRD) with copper lamp, $P W X^{\prime}$ Pert 3020 (Philips). The correctness of analytical methods was assessed through analysis of quality control samples, the reference materials and the samples derived from interlaboratory comparisons ISE (International Soil-Analytical Exchange, Wageningen).

\section{Results and Discussion}


The first research step, concerning the analysis of 9860 soils samples treated with aqua regia, showed that the average content of tin was $<2 \mathrm{mg} \cdot \mathrm{kg}^{-1}$ and $<0.5 \mathrm{mg} \cdot \mathrm{kg}^{-1}$ for molybdenum. In the 261 samples the tin concentration exceeded $2 \mathrm{mg} \cdot \mathrm{kg}^{-1}$, including 34 samples, in which tin concentration was above $20 \mathrm{mg} \cdot \mathrm{kg}^{-1}$ - the limit allowed for soil in according ordinance of the Ministry of
Environment [6]. In the case of molybdenum analysis, 2242 samples were above the average content, including 3 samples, which were above $10 \mathrm{mg} \cdot \mathrm{kg}^{-1}$ - the limit allowed for soil in according ordinance of the Ministry of Environment [6]. Statistical data, including average content, median and maximum concentration of analyzed elements are listed in Table 1.

Table 1. Statistical data of results obtained from analysis of samples collected in $2007 / 2008^{1}$ and $2011^{2}$ year

\begin{tabular}{|c|c|c|c|c|}
\hline $\begin{array}{l}\text { Soil type } \\
\text { (no. of samples) }\end{array}$ & $\begin{array}{l}\text { Topsoil }^{1} \\
(5223)\end{array}$ & $\begin{array}{c}\text { Subsoil }^{1} \\
(4637)\end{array}$ & $\begin{array}{c}\text { Topsoil }^{2} \\
\text { (33) }\end{array}$ & $\begin{array}{l}\text { Subsoil }^{2} \\
(27)\end{array}$ \\
\hline \multicolumn{5}{|c|}{ Mo $\left[\mathrm{mg} \cdot \mathrm{kg}^{-1}\right]$} \\
\hline Minimum & $<0,5$ & $<0,5$ & $<0,5$ & $<0,5$ \\
\hline Median & $<0,5$ & $<0,5$ & 1,1 & 1,1 \\
\hline Mean & $<0,5$ & $<0,5$ & 2,5 & 2,4 \\
\hline Percentile 75 & 0,6 & $<0,5$ & 2,4 & 2,7 \\
\hline Percentile 90 & 0,9 & 0,6 & 7,8 & 7,0 \\
\hline Percentile 95 & 1,4 & 0,9 & 9,4 & 8,5 \\
\hline Percentile 97 & 1,7 & 1,2 & 10,0 & 8,9 \\
\hline Maximum & 28,0 & 8,9 & 11,5 & 9,8 \\
\hline \multicolumn{5}{|c|}{ Sn $\left[\mathrm{mg} \cdot \mathrm{kg}^{-1}\right]$} \\
\hline Minimum & $<2$ & $<2$ & $<2$ & $<2$ \\
\hline Median & $<2$ & $<2$ & $<2$ & $<2$ \\
\hline Mean & $<2$ & $<2$ & 5 & 4 \\
\hline Percentile 75 & $<2$ & $<2$ & 3 & $<2$ \\
\hline Percentile 90 & 2,6 & $<2$ & 20 & 7 \\
\hline Percentile 95 & 3,6 & $<2$ & 26 & 16 \\
\hline Percentile 97 & 4,9 & 2,2 & 28 & 21 \\
\hline Maximum & 295 & 1460 & 36 & 32 \\
\hline
\end{tabular}

Results obtained from the first part of the studies allowed for densification and selection of proper sampling sites. A total of 33 sites and 60 soil samples were selected for further analysis.

Interestingly, the average of tin concentration detected in soil samples collected in 2011 were significantly higher than in samples taken in 2008. However, the maximum concentration of tin was definitely lower in samples derived from second round of collection (Table 1). For 27 samples, from the second round, the tin concentration was above the $2 \mathrm{mg} \cdot \mathrm{kg}^{-1}$, including five samples in which exceeded $20 \mathrm{mg} \cdot \mathrm{kg}^{-1}$. Most of the samples with high tin content $\left(>20 \mathrm{mg} \cdot \mathrm{kg}^{-1}\right)$ were collected from the topsoil, thus it can be assumed that it has anthropogenic origin. Extremely valuable information obtained from these data was also the correlation between the occurrence of tin with other elements. All samples with high levels of tin contained a high concentration of $\mathrm{Zn}, \mathrm{Pb}, \mathrm{Cu}$. In addition to those correlations, an interesting anomaly was detected in samples derived from paper mill of Czułów. Samples from the topsoil and its counterpart from the subsoil contain very high iron content $(7.53 \%$ and $6.07 \%)$, arsenic $(902 \mathrm{mg} / \mathrm{kg}$ and $555 \mathrm{mg} / \mathrm{kg})$ and sulfur $(3.035 \%$ and $3.027 \%)$.

Similarly to tin, the average concentration of molybdenum detected in soil samples collected in 2011 were higher than in samples from 2008. The maximum molybdenum concentrations in samples collected from the topsoil in 2011 was significantly lower than in samples from the topsoil collected in 2008 (Table 1). However the maximum molybdenum concentrations in the samples from the subsoil collected in different years was very similar. The concentrations of molybdenum exceeding $10 \mathrm{mg} \cdot \mathrm{kg}^{-1}$ (the limit allowed for soil in according ordinance of the Ministry of Environment) was noted only in two topsoil samples. In turn, below the detection limit $\left(0.5 \mathrm{mg} \cdot \mathrm{kg}^{-1}\right)$ only six samples were recorded. In contrast to the tin, there was no correlation between molybdenum and other elements.

The results of the sequential extraction showed minimal bioavailability of tin (Fig. 1) and molybdenum (Fig. 2) in samples of soil. There is almost a $99 \%$ leaching efficiency of both elements in the final 4th stage of extraction after the aqua regia treatment. In addition to the sequential extraction, X-ray diffraction (XRD) analysis was performed. The aim of this analysis was to verify the occurrence of anomalous origin of the source of $\mathrm{Sn}$ and Mo. The XRD analysis of soil samples showed the lack of tin and molybdenum minerals in the investigated soil. This analysis showed among predominant minerals were quartz, calcite, feldspar and clay minerals. In some samples, additional minerals like mullite, maghemite, jarosite and gipsum 


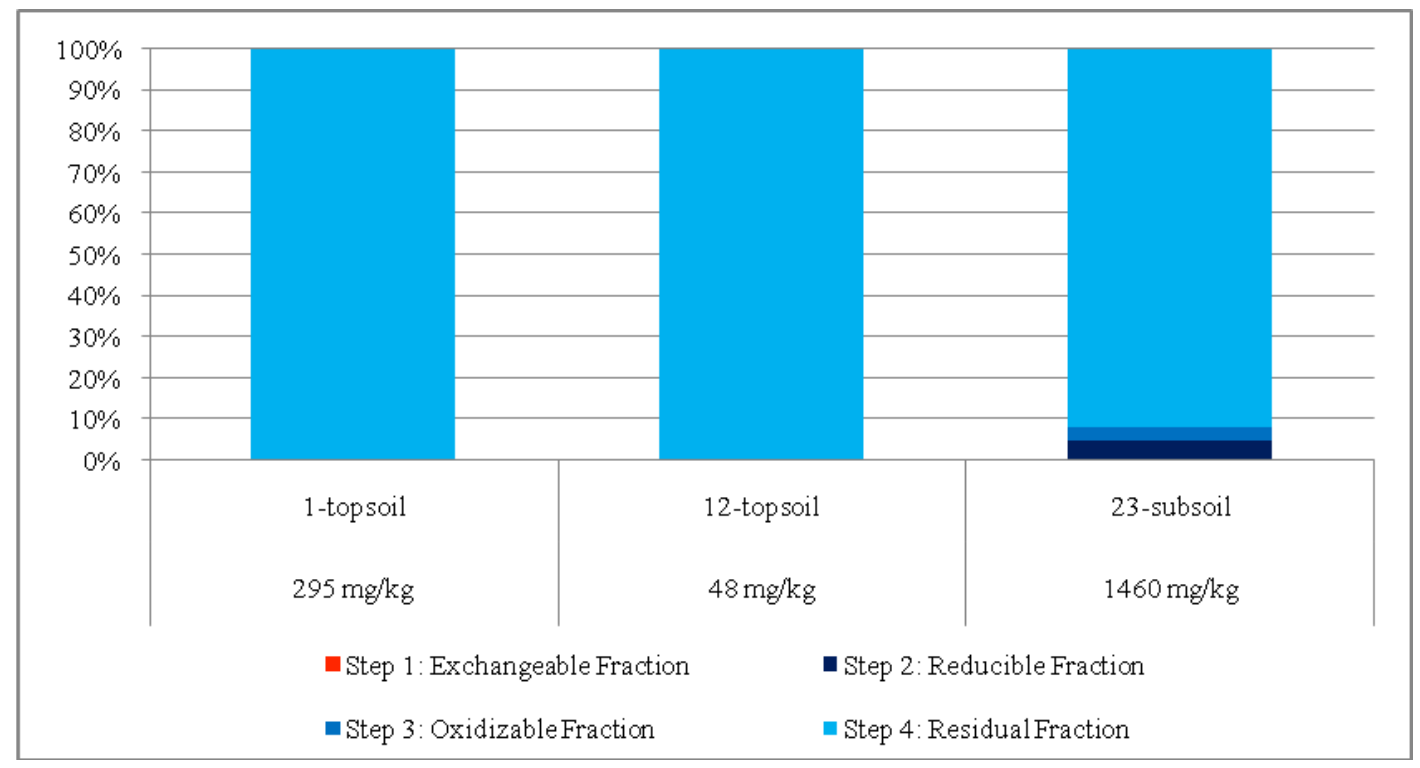

Fig. 1 Distribution of Sn in sequentially extracted fraction of soils 1, 12 and 23

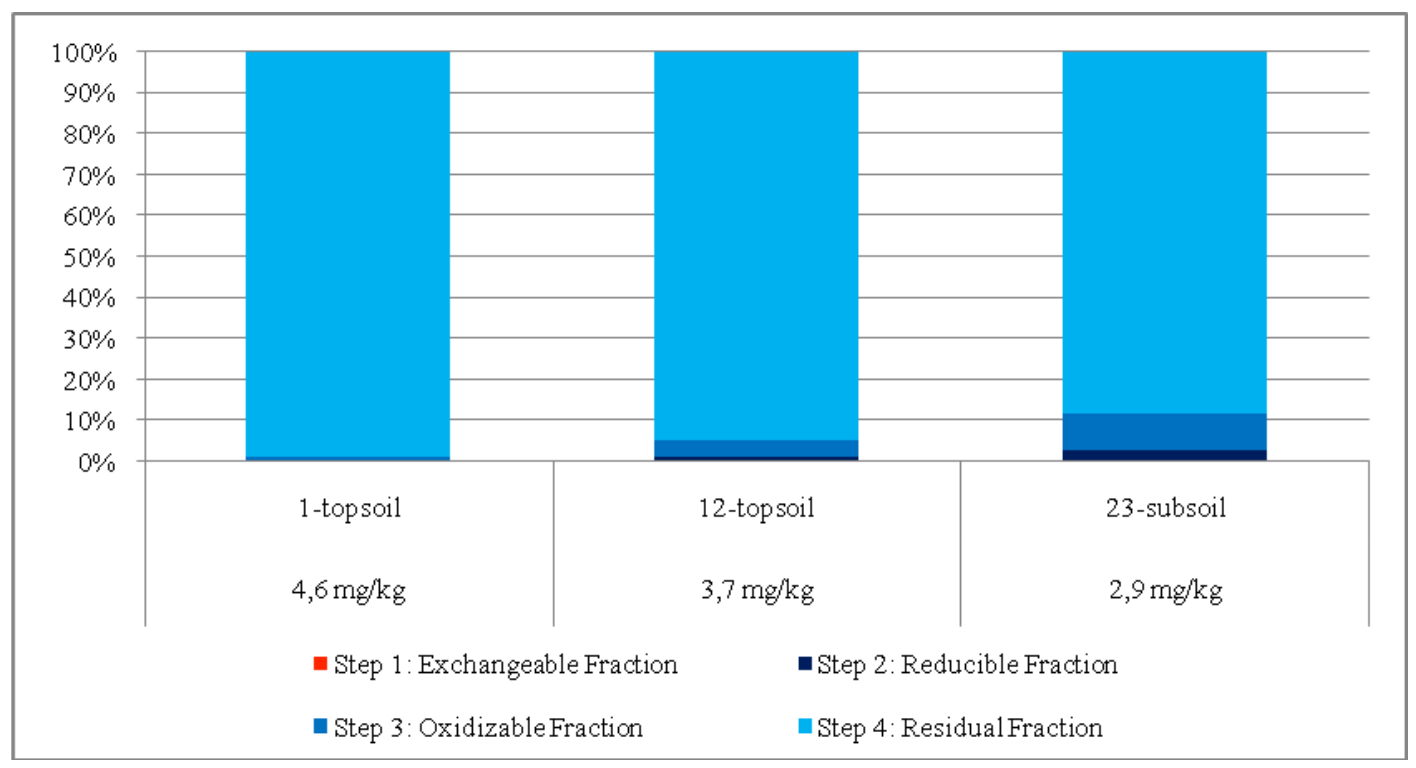

Fig. 2 Distribution of Mo in sequentially extracted fraction of soils 1, 12 and 23

were also observed. Based on literature data it is predicted that the occurrence of these minerals may be associated with human activity.

\section{Acknowledgements}

Samples from the first stage of the research derived from the project „Detailed geochemical map of Upper Silesia 1:25 000" (Sheet: Katowice, Mysłowice, Bierun Stary, Imielin) preformed by the Polish Geological Institute - National Research Institute. All studies were performed under the project "Geochemistry of tin and molybdenum in the southern part of the Silesian Uplands" (no. 61-3207-1101-00-0).

\section{References}

[1] A. Pasieczna, Detailed geochemical map of Upper Silesia 1:25000

[2] A. Kabata-Pendias, Trace Elements in Soils and Plants, CRC Press Inc., Boca Raton 2001

[3] PASIECZNA A., KWECKO P., 2010 - Projekt GEMAS - zdjęcie geochemiczne gleb użytkowanych rolniczo i łąk w Europie. Prz. Geol. 5: 397-400. (in Polish).

[4] G. Rauret, J. F. López-Sánchez, A. Sahuquillo, R. Rubio, C. Davidson, A. Ure et al., J. Environ. Monit., 1 (1999) 57-61.

[5] J. M. Hernández-Moreno, J. I. Rodríguez-González, M. Espino-Mesa, Eur. J. Soil Sci., 58 (2007) 419430.

[6] Rozporządzenie Ministra Środowiska z dnia 9 września 2002 r. w sprawie standardów jakości gleby oraz standardów jakości ziemi (in Polish). 